\title{
ROLA BANKU OCHRONY ŚRODOWISKA SA W KRAJOWYM SYSTEMIE FINANSOWANIA PRZEDSIĘWZIĘĆ PROEKOLOGICZNYCH
}

\author{
Robert Turek \\ Politechnika Częstochowska \\ Wydział Zarządzania
}

\begin{abstract}
Streszczenie: W opracowaniu podjęto rozważania odnoszące się do proekologicznej działalności banku BOŚ SA, w szczególności do określenia jego roli w finansowaniu przedsięwzięć proekologicznych. Opracowanie zostało podzielone na dwie części. I tak rozważania części pierwszej koncentrują się na charakterystyce form kredytowania przedsięwzięć proekologicznych realizowanych na rynku polskim. Rozważania części drugiej skupione są na analizie oferty preferencyjnych kredytów proekologicznych udzielanych przez BOŚ SA.
\end{abstract}

Słowa kluczowe: przedsięwzięcia proekologiczne, ekokredyt, kredyty preferencyjne, proekologiczne kredyty preferencyjne, BOŚ SA

DOI: $10.17512 /$ znpcz.2017.4.2.09

\section{Wprowadzenie}

Niewątpliwie ważne zagadnienie współczesnego życia gospodarczego stanowi problematyka ochrony środowiska. Wynika to z faktu, iż kurczące się zasoby naturalne, a przede wszystkim działalność wielu przedsiębiorstw, przyczyniły się do postępującej degradacji środowiska naturalnego. Jeszcze do niedawna Polska była jednym z najbardziej zanieczyszczonych krajów Europy, a 30\% jej mieszkańców żyło na obszarach ekologicznego zagrożenia. Powodem takiego stanu rzeczy był intensywny rozwój przemysłu na przełomie lat 70. i 80. XX wieku, a także niskie wydatki na ochronę środowiska, które wynosiły zaledwie 0,2-0,5\% PKB (System finansowania..., 2013, s. 4). Jednym z ważniejszych i najbardziej kompleksowych opracowań tego okresu była Przestrzenna diagnoza ochrony środowiska w Polsce, w której to przedstawiono szczegółową analizę stanu środowiska naturalnego w Polsce, na podstawie której wyznaczono i opisano obszary ekologicznego zagrożenia (NFOŚiGW 2009, s. 11). Z tego też względu priorytetem ówczesnych działań nie była naprawa błędów już popełnionych, ale zabezpieczenie środowiska przed ryzykiem popełnienia następnych. Taka sytuacja wymagała z kolei zdecydowanych działań systemowych ze strony państwa. Dlatego też wprowadzono w życie szereg uwarunkowań prawnych, których celem było i nadal jest umożliwienie - w myśl koncepcji zrównoważonego rozwoju - korzystania z zasobów środowiska przyszłym pokoleniom oraz prawo do życia w środowisku o należytej jakości, w stanie nie gorszym niż obecnie (Ciechanowicz-McLean 2009, s. 21; Kościelniak 2014, s. 5732). 
Znaczącym impulsem w tworzeniu mechanizmów ograniczających negatywny wpływ gospodarki na środowisko naturalne były obrady Okrągłego Stołu, w trakcie których powstało 28 postulatów dotyczących działań na rzecz środowiska naturalnego. Ponadto ustalenia podczas obrad znalazły swój wyraz w nowelizacji ustawy o ochronie i kształtowaniu środowiska, a także w zarządzeniu nr 11 Ministerstwa Ochrony Środowiska, Zasobów Naturalnych i Leśnictwa (MOŚZNiL) z 15 lipca 1989 r., na mocy których powstał Narodowy Fundusz Ochrony Środowiska i Gospodarki Wodnej (NFOŚiGW). Fundusz stał się podstawą do budowy unikalnego w skali świata, stabilnego systemu finansowania ochrony środowiska i gospodarki wodnej w Polsce (NFOŚiGW 2009, s. 8-9). W systemie tym, opartym na funduszach ekologicznych (NFOŚiGW, jego wojewódzkie, powiatowe i gminne odpowiedniki, Fundusz Ochrony Gruntów Rolnych, Fundusz Leśny), współdziałają banki, traktując zadania z zakresu ochrony środowiska jako dobrze rokujący rynek do ich ekspansji kredytowej. Banki, pełniąc rolę pośrednika, zapewniają sobie wymierne korzyści przy relatywnie niewielkim poziomie ryzyka, dlatego chętnie tworzą oferty przyciągające inwestorów (Gabryś 2007, s. 185).

Opracowanie ma charakter teoretyczno-praktyczny, a przedstawione rozważania odnoszą się do określenia roli BOŚ SA w finansowaniu przedsięwzięć proekologicznych. Celem opracowania jest ocena dotychczasowych działań BOŚ SA w finansowaniu przedsięwzięć ekologicznych. W takim odniesieniu rozważania w pierwszej kolejności koncentrują się na charakterystyce form kredytowania realizowanych na rynku polskim przedsięwzięć proekologicznych, w drugiej zaś na analizie oferty banku, ze szczególnym uwzględnieniem udzielanych preferencyjnych kredytów proekologicznych na realizację szeregu przedsięwzięć proekologicznych.

\section{Źródła finansowania przedsięwzięć proekologicznych}

W ciągu ostatniego dziesięciolecia odnotować można rozwój przedsięwzięć proekologicznych w Polsce, mających na celu ochronę: niekorzystnych zmian klimatu, zasobów naturalnych, zanieczyszczenia powietrza, bioróżnorodności gatunkowej (Macherzyński, Nowodziński 2017, s. 53). Z tego też względu coraz więcej współczesnych przedsiębiorstw podejmuje się realizacji inwestycji na rzecz ochrony środowiska. Wiadomym jest, iż realizacja takich działań wymaga znacznych nakładów finansowych. W związku z tym istotnego znaczenia nabiera proces ich finansowania.

Finansowanie przedsięwzięć z zakresu polityki ekologicznej dynamicznie rozwija się na rynku usług finansowych. Wyniki, jakie osiąga Polska w tym segmencie rynku, są konsekwencją skutecznego i zintegrowanego systemu finansowania tworzonego na początku lat 90 . XX wieku. Podstawę tego systemu stanowią celowe fundusze ekologiczne - Narodowy Fundusz Ochrony Środowiska i Gospodarki Wodnej (NFOŚiGW) oraz fundusze wojewódzkie (Wojewódzki Fundusz Ochrony Środowiska i Gospodarki Wodnej - WFOŚiGW), które są rozwinięciem roli państwa w finansowaniu działań z zakresu ochrony środowiska (Famielec 2005, 
s. 120). System ten współtworzą inwestorzy, a wspierają i uzupełniają m.in. banki komercyjne udzielające pożyczek i kredytów.

System ten stanowi integralną część systemu finansowego państwa, obejmując swym zakresem zbiór zasad i przepisów określających sposoby, tryb gromadzenia i redystrybucji środków pieniężnych na przedsięwzięcia proekologiczne. Został on ukształtowany przed integracją Polski z Unią Europejską i oparty na odmiennej filozofii i źródłach prawa (Poskrobko, Ejdys 2005, s. 100). Jak podkreślają B. Poskrobko i T. Poskrobko, w polskim prawie działalność na rzecz ochrony środowiska ukierunkowana jest na efekty środowiskowe, gdzie przepisy unijne charakteryzują się podejściem technologicznym. Oznacza to zobowiązanie użytkowników środowiska do bezwzględnego respektowania standardów produktowych i emisyjnych (Poskrobko, Poskrobko 2012, s. 83).

W praktyce wsparcie przedsięwzięć proekologicznych skierowane jest zarówno do tych uczestników rynku, których działalność w negatywny sposób wpływa na środowisko naturalne, jak i do tych, którzy z jednej strony dążą do poprawy istniejącego stanu, z drugiej zaś mają na celu przeciwdziałanie negatywnym skutkom, które dopiero mogą nastąpić.

Podział źródeł finansowania zadań z zakresu ochrony środowiska przedstawiono na Rysunku 1.

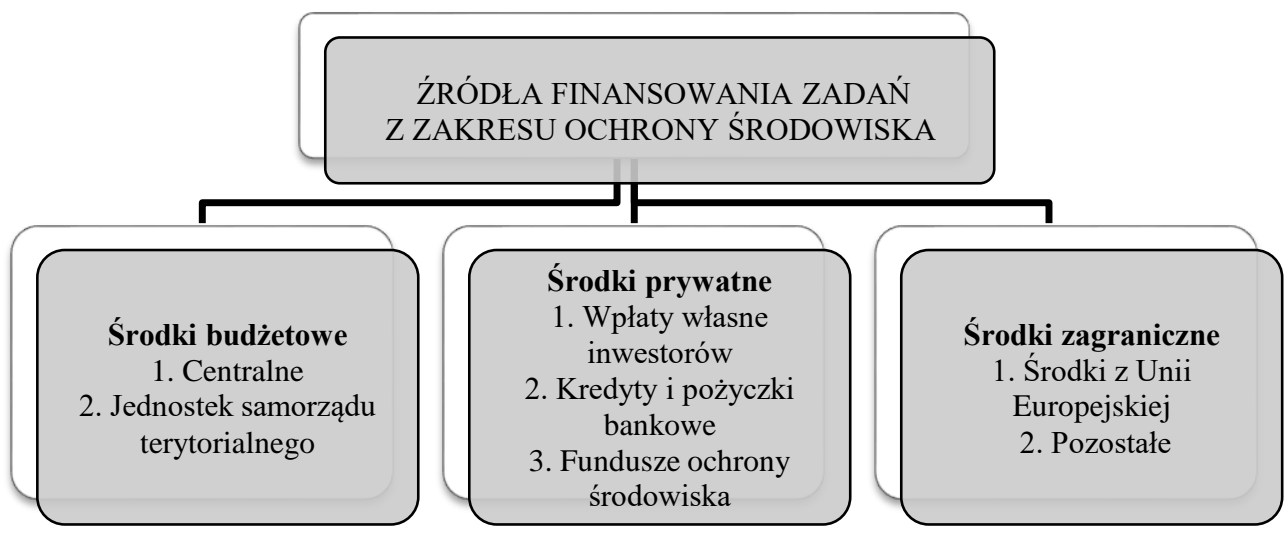

Rysunek 1. Źródła finansowania zadań z zakresu ochrony środowiska w Polsce

Źródło: (Barczak, Kowalewska 2014, s. 40)

Należy w tym miejscu podkreślić, iż finansowanie przedsięwzięć ekologicznych może:

odbywać się zarówno w pośredni, jak i bezpośredni sposób,

pochodzić z krajowych, jak i zagranicznych źródeł,

pochodzić z kilku źródeł naraz.

Obieg środków z uwzględnieniem instytucji finansujących inwestycje ekologiczne oraz odbiorców końcowych przedstawiono na Rysunku 2. 


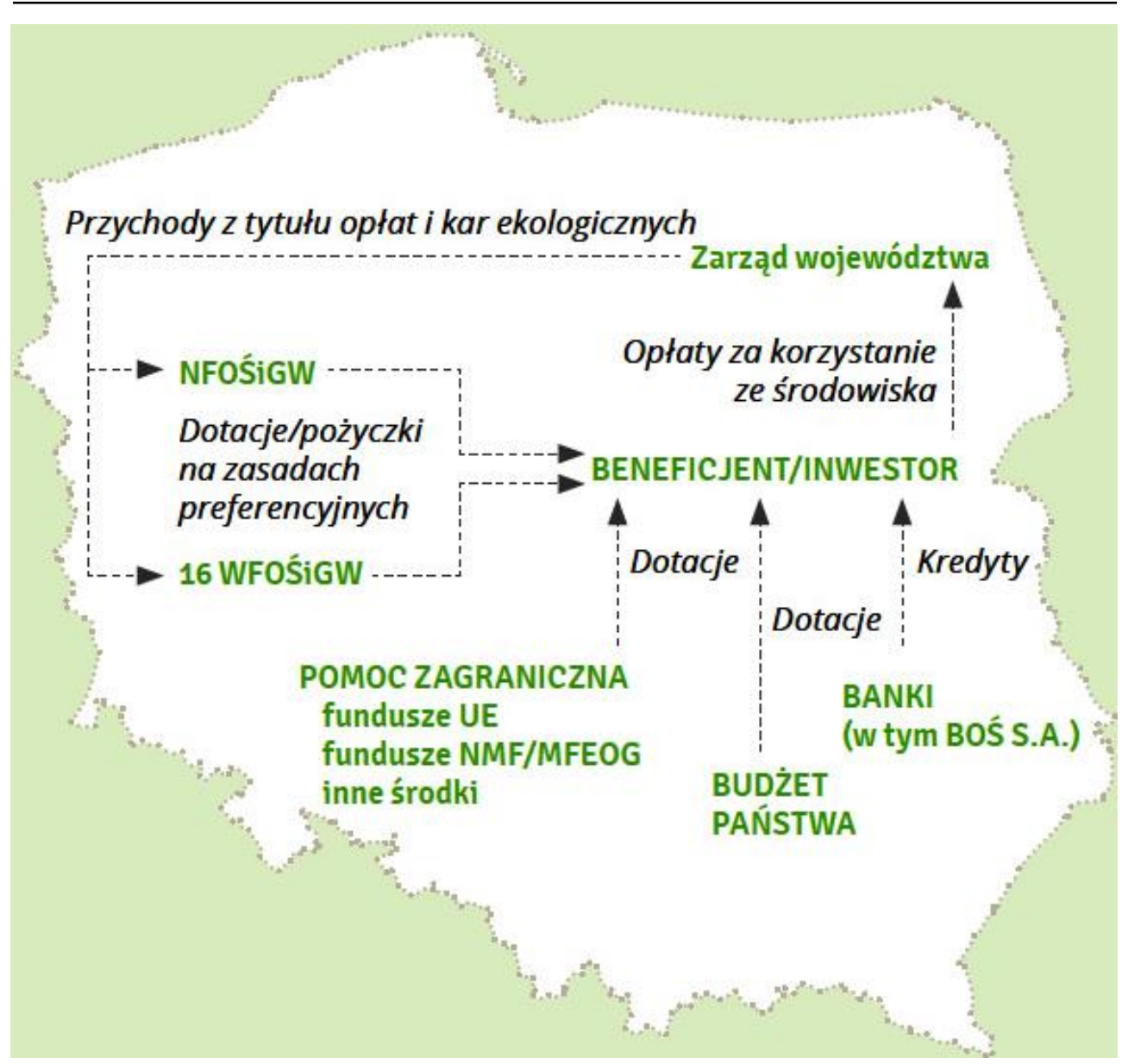

Rysunek 2. System i główne źródła finansowania ochrony środowiska w Polsce

Źródło: www.nfosigw.gov.pl

W sposób pośredni, krajowy inwestycje dotyczące ochrony środowiska finansowane są przez budżet, udzielając subsydiów dla gmin, poprzez stosowanie ulg i zwolnień podatkowych wobec podmiotów prowadzących działalność gospodarczą oraz osób fizycznych, jeśli podejmują się realizacji zadań z zakresu ochrony środowiska (Barczak, Kowalewska 2014, s. 41). Z kolei bezpośrednie finansowanie odnosi się do finansowania przedsięwzięć proekologicznych ze środków własnych inwestorów (przedsiębiorców lub osób fizycznych), pochodzących z dwóch źródeł: środków bieżących, kredytów i pożyczek - w tym udzielanych preferencyjnie przez Bank Ochrony Środowiska (BOŚ), Bank Gospodarstwa Krajowego (BGK) oraz przez banki komercyjne (Kłos 2015, s. 130). Szczególnym źródłem finansowania zadań ochrony środowiska są ekologiczne fundusze ochrony środowiska, działające na czterech szczeblach (Rysunek 3). 


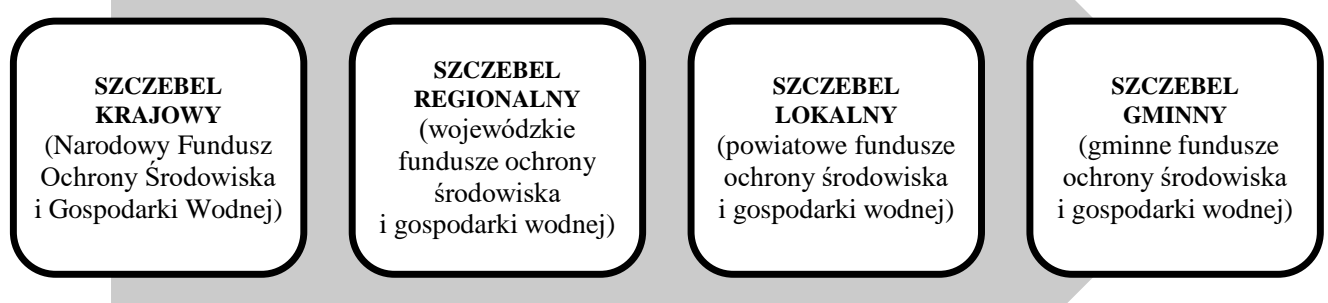

\section{Rysunek 3. Cztery szczeble funduszy ekologicznych}

Źródło: Opracowanie własne

Instytucję wiodącą w systemie finansowania ochrony środowiska w Polsce stanowi NFOŚiGW, finansując lub współfinansując przedsięwzięcia proekologiczne ze środków własnych i będących $w$ jego dyspozycji lub obsługiwanych przez niego środków europejskich. Należy zaznaczyć, iż NFOŚiGW dofinansowuje ochronę środowiska i gospodarkę wodną, stosując bezzwrotne i zwrotne formy finansowego wsparcia (Rysunek 4).

W ciągu 27 lat wsparcie udzielone przez NFOŚiGW dla przedsięwzięć proekologicznych wyniosło ogółem aż 68 mld zł, z czego:

- $\quad 41$ mld zł stanowiły środki własne,

- $\quad 27$ mld zł stanowiły środki zagraniczne, głównie z Unii Europejskiej.

Łącznie w tym okresie podpisano 30139 umów związanych w znacznej mierze z ochroną wód, gospodarką wodną, gospodarką odpadami, ochroną powierzchni ziemi, ochroną powietrza, rolnictwa ekologicznego czy wykorzystania lokalnych źródeł energii odnawialnej (www.nfosigw.gov.pl). Obok NFOŚiGW istotną rolę w procesie finansowania przedsięwzięć proekologicznych ogrywają fundusze ekologiczne na szczeblu wojewódzkim - WFOŚiGW. W okresie 2007-2015

- WFOŚiGW wydatkowały na ochronę środowiska i gospodarkę wodną 19,1 mld zł,

- $\quad$ z tego:

- $\quad$ pożyczki z preferencyjnym oprocentowaniem - 14,4 mld zł;

finansowanie dotacyjne $-4,7 \mathrm{mld} z$;

inwestycje kapitałowe $-10 \mathrm{mln}$ zł. 


\section{FORMY BEZZWROTNE}

- dotacje na realizację zadań inwestycyjnych i nieinwestycyjnych,

- dopłaty do oprocentowania kredytów bankowych,

- umorzenia pożyczek,

- częściowa spłata kapitału kredytów bankowych,

- dopłaty do oprocentowania lub ceny wykupu obligacji,

- dopłaty do demontażu pojazdów wycofanych z eksploatacji i dopłaty dla powiatów i gmin za zbiórkę porzuconych na ich terenie pojazdów.

\section{FORMY ZWROTNE}

- z preferencyjnym oprocentowaniem,

- inwestycje kapitałowe.

\section{Rysunek 4. Formy wsparcia NFOŚiGW}

Źródło: Opracowanie własne na podstawie (MŚ 2016, s. 20)

Strukturę wsparcia WFOŚiGW w latach 2007-2015 przestawiono na Rysunku 5.

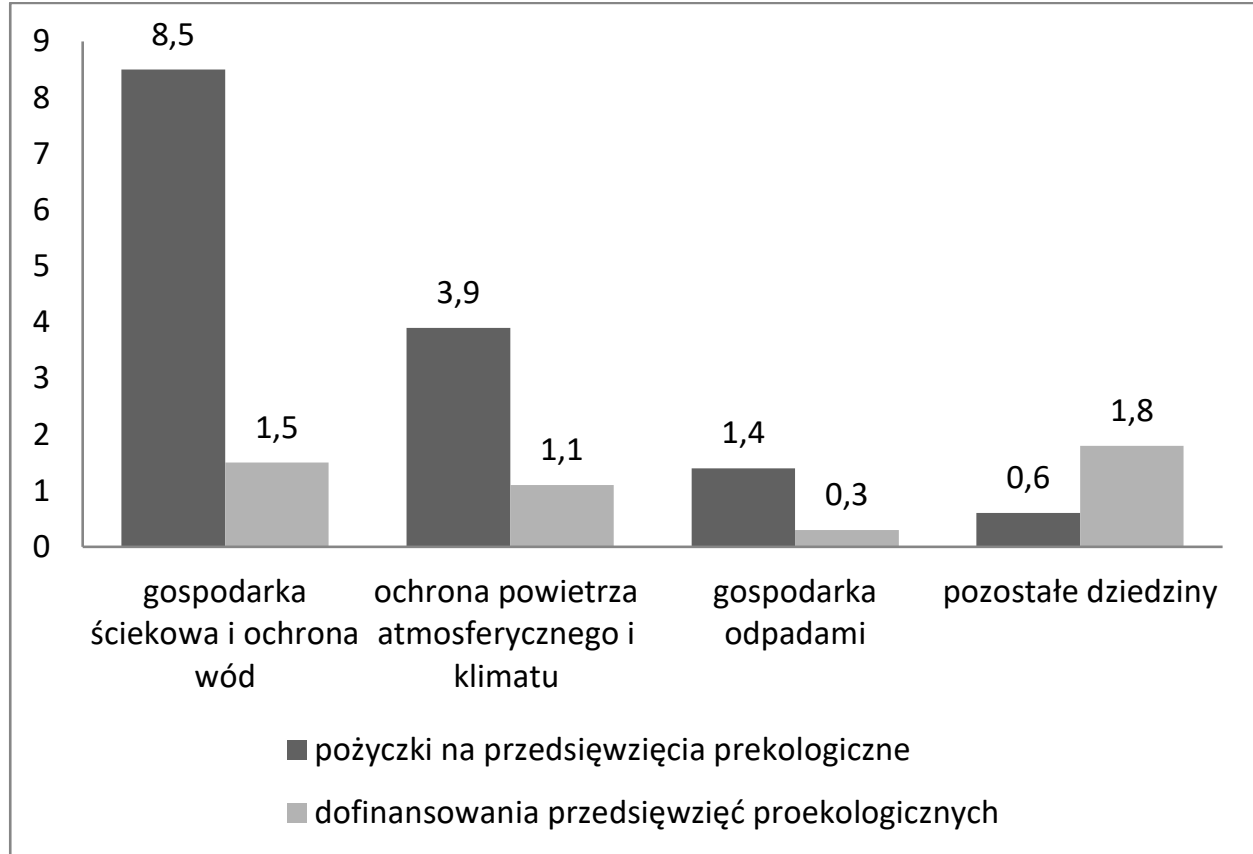

Rysunek 5. Struktura wsparcia WFOŚiGW w latach 2007-2015

Źródło: Opracowanie własne na podstawie (MŚ 2016, s. 23) 
Specyficzny fundusz w systemie finansowania działań na rzecz ochrony środowiska stanowi Fundusz Leśny, którego środki przeznaczone są głównie na wyrównywanie niedoborów środków finansowych w nadleśnictwach, a także szeregu zadań z zakresu gospodarki leśnej. W systemie finansowania ochrony środowiska, opartym na funduszach ekologicznych, dużą rolę odgrywają banki. $\mathrm{Z}$ tego też względu banki sukcesywnie rozszerzają swoją ofertę kredytową oraz podnoszą jej atrakcyjność, zarówno pod względem warunków, dostępności i oprocentowania, jak też pod względem wielkości finansowanego kredytu i długości okresu jego spłaty. Znaczącym źródłem finansowania projektów z zakresu ochrony środowiska są środki zagraniczne, a przede wszystkim środki unijne. Środki te mają z reguły postać dotacji dewizowych i darowizn, są przyznawane na podstawie umów i porozumień międzynarodowych oraz protokołów, oświadczeń i porozumień podpisanych przez upoważnione agendy rządowe Polski i państw wspierających finansowo realizację projektów ochrony środowiska (Toruński, Wyrębek 2010, s. 20-21).

W praktyce wybór i stosowanie określonej formy i źródła finansowania zależy przede wszystkim od rodzaju proekologicznego przedsięwzięcia, rodzaju wnioskodawcy, a także rodzaju instytucji finansującej. Z uwagi na cel opracowania dalsze rozważania koncentrują się wokół banku BOŚ SA.

\section{BOŚ SA w systemie wsparcia przedsięwzięć proekologicznych ${ }^{1}$}

\section{Proekologiczna dzialalność BOŚ SA}

Jednym z 38 banków komercyjnych działających na polskim rynku finansowym, a zarazem jedynym bankiem specjalizującym się w finansowaniu przedsięwzięć proekologicznych jest Bank Ochrony Środowiska SA - BOŚ SA.

Filarem jego działalności jest szeroko pojmowana ekologia, o czym świadczy proekologiczna misja banku: „wspieranie przedsięwzięć stużących rozwojowi przemystu $i$ ustug $w$ zakresie ochrony środowiska, rozwojowi rynku produktów $i$ ustug zwiazanych z ekologia oraz promowanie i kreowanie postaw proekologicznych i inicjatyw na rzecz ochrony środowiska naturalnego", wpisana w jego statut od samego początku jego istnienia, czyli od 1991 roku. Realizacja prośrodowiskowej misji znajduje swoje odzwierciedlenie w założeniach polityki środowiskowej, którą BOŚ SA konsekwentnie realizuje (Rysunek 6). Również struktura akcjonariatu w naturalny sposób tworzy pole dla ścisłej współpracy i wzajemnego wsparcia przy rozwijaniu rynku finansowania przedsięwzięć proekologicznych $\mathrm{w}$ Polsce (Rysunek 7).

\footnotetext{
${ }^{1}$ Studium przypadku zostało opracowane na podstawie wewnętrznych materiałów BOŚ SA, a także raportów ekologicznych i sprawozdań finansowych.
} 
respektowanie obowiazującego prawa w zakresie ochrony środowiska i uwzględnianie jego wymogów w przepisach wewnętrznych

ograniczenie wykorzystania surowców i zasobów naturalnych poprzez racjonalizację zużycia wody, energii elektrycznej, ciepła i paliw

popularyzacja wśród pracowników BOS SA wiedzy na temat
proekologicznych zachowań, podnoszenie ich świadomości
i kształtowanie postaw

prowadzenie praktyki zakupów materiałów i urządzeń z uwzględnieniem jako jednego $\mathrm{z}$ istotnych parametrów, jak najmniejszego ich wpływu na środowisko

prowadzenie racjonalnej gospodarki odpadami poprzez ograniczenie ich powstawania, selektywną zbiórkę i przekazywanie do recyklingu bądź unieszkodliwianie

promowanie zrównoważonego rozwoju wśród partnerów biznesowych i firm współpracujących z Bankiem

współpraca z instytucjami i organizacjami, których cele są ukierunkowane na ochronę środowiska oraz edukację nt. ekologii

\section{Rysunek 6. Założenia polityki środowiskowej BOŚ SA}

Źródło: Opracowanie własne na podstawie wewnętrznych materiałów BOŚ SA

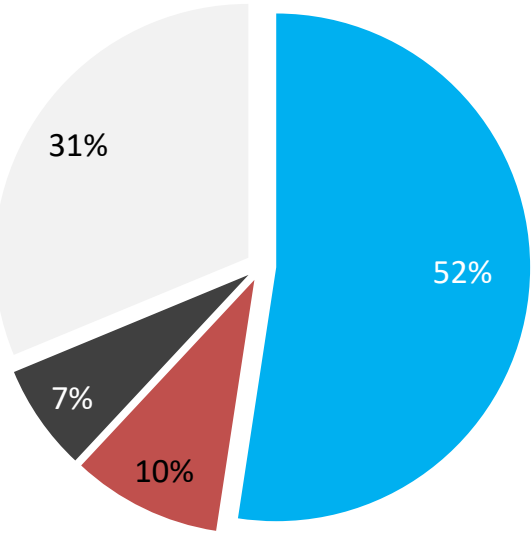

Narodowy Fundusz Ochrony Środowiska i Gospodarki Wodnej

- Fundusz Inwestycji Polskich Przedsiębiorstw Fundusz Inwestycyjny Zamknięty Aktywów

Niepublicznych

- Dyrekcja Generalna Lasów

Państwowych

Akcje w wolnym obrocie

\section{Rysunek 7. Struktura akcjonariatu BOŚ SA}

Źródło: Wewnętrzne materiały BOŚ SA 
Jak można zauważyć (Rysunek 7), większościowy udział w strukturze akcjonariatu ma Narodowy Fundusz Ochrony Środowiska i Gospodarki Wodnej (NFOŚiGW), który - jak już wspominano - od 27 lat stanowi najważniejsze ogniwo polskiego systemu finansowania różnego rodzaju inwestycji proekologicznych. Proekologiczny charakter BOŚ SA widoczny jest również w przyjętej w 2016 roku Strategii Rozwoju Banku Ochrony Środowiska na lata 2016-2020, w której to BOŚ SA stawia na „ekologię czasu”, czyli nowoczesną bankowość, wysoką jakość i szybkość obsługi. Z tego też względu BOŚ SA w swoich działaniach kieruje się maksymą:

BOŚ Bank - z korzyścią dla Ciebie i świata, w którym żyjesz.

Podsumowując, można powiedzieć, że BOŚ SA w swoich działaniach kieruje się nie tylko dbałością o dobro klientów banku, ale przede wszystkim o środowisko naturalne. $\mathrm{W}$ tym celu zobowiązuje się do ciągłego minimalizowania negatywnego wpływu na środowisko naturalne, prowadząc kompleksowe działania, o czym świadczy wypełnianie założeń polityki środowiskowej. Proekologiczną działalność banku zauważyć można w szerokiej ofercie BOŚ SA.

\section{Proekologiczna oferta kredytowa BOŚ SA}

BOŚ SA dzięki współpracy z NFOŚiGW, a także WFOŚiGW posiada w swojej ofercie szeroką gamę preferencyjnych kredytów, przeznaczonych na realizację szeregu przedsięwzięć proekologicznych, zarówno dla klientów pionu detalicznego, korporacji, jak i finansów publicznych (Rysunek 8). Do końca roku 2016 BOŚ SA udzielił łącznie 18,6 mld zł kredytów proekologicznych, a dzięki finansowemu wsparciu zrealizowano w tym okresie ponad 59 tys. przedsięwzięć inwestycyjnych, których łączna wartość wyniosła ok. 50 mld zł.

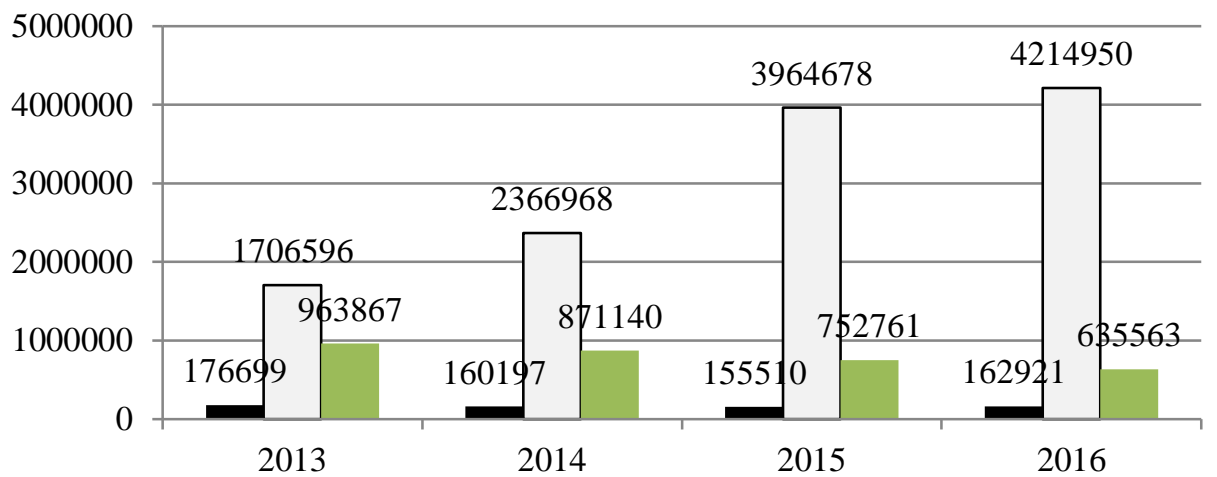

- Kredyty proekologiczne udzielone klientom detalicznym

$\square$ Kredyty proekologiczne udzielone klientom korporacyjnym

Kredyty proekologiczne udzielone finansom publicznym

Rysunek 8. Struktura segmentowa kredytów proekologicznych BOŚ SA

Źródło: Opracowanie własne na podstawie wewnętrznych materiałów BOŚ SA 
Analizując dane zamieszczone na Rysunku 8, można stwierdzić, iż średnio 92\% wszystkich kredytów proekologicznych stanowią kredyty skierowane do klientów korporacyjnych. Co więcej, w segmencie tym obserwuje się rosnącą liczbę inwestycji proekologicznych, a zatem wzrost zapotrzebowania na kredyty proekologiczne. $Z$ tego też względu BOŚ SA sukcesywnie poszerza gamę produktów skierowaną do tej grupy klientów przy wykorzystaniu synergii z NFOŚiGW. Jako przykład można podać kredyt Eko Inwestycje, którego celem jest wsparcie inwestycji związanych z produkcją energii ze źródeł odnawialnych oraz poprawa efektywności energetycznej w budynkach. Zaletą tego kredytu jest okres kredytowania wydłużony do 20 lat oraz niewymagany wkład własny.

Odwrotną z kolei tendencję zauważyć można w przypadku pionu finansów publicznych. Spadek udziału BOS SA w tym segmencie zgodny jest z przyjętą strategią, zgodnie z którą BOŚ SA uwzględnia proces konsolidacji finansów publicznych i dążenie do zmiany struktury bilansu na rzecz klientów korporacyjnych, $\mathrm{z}$ uwagi na ich wyższą rentowność. $\mathrm{Z}$ kolei w przypadku pionu klientów detalicznych (osób fizycznych, mikroprzedsiębiorstw, wspólnot mieszkaniowych, organizacji pozarządowych i innych instytucji niekomercyjnych (NGO)) zauważyć można lekkie zróżnicowane, co związane jest $\mathrm{z}$ dostępnością dla tej grupy klientów linii kredytowych.

Finansowanie przedsięwzięć proekologicznych możliwe jest także dzięki udzielaniu przez BOŚ SA kredytów preferencyjnych z dopłatami WFOŚiGW. Jak można zauważyć (Rysunek 9), oferta banku różni się w zależności od przeznaczenia kredytu, liczby oferowanych kredytów, a także lokalizacji inwestycji. I tak najwięcej kredytów preferencyjnych bank oferuje w województwie kujawsko-pomorskim oraz wielkopolskim, najmniej zaś w podkarpackim. Należy zaznaczyć, iż BOŚ SA zapewnia możliwość finansowania inwestycji do $90 \%$ kosztów proekologicznego przedsięwzięcia, elastyczny czas kredytowania od 5 do 12 lat, a także dopłatę do kapitału (do 40\% kosztów danej inwestycji).

$\mathrm{Z}$ uwagi na fakt, iż pion klientów detalicznych stanowi najliczniejszą grupę klientów, BOŚ SA co roku podejmuje działania związane $\mathrm{z}$ uatrakcyjnieniem oferty, zarówno modyfikując funkcjonujące produkty, jak również wprowadzając nowe, innowacyjne rozwiązania. Obecnie w ofercie kredytów preferencyjnych znajduje się:

EKOkredyt obrotowy dla mikroprzedsiębiorstw na finansowanie bieżącej działalności w zakresie: montażu systemów dociepleniowych, montażu kotłów centralnego ogrzewania, budowy przydomowych oczyszczalni ścieków, inwestycji w odnawialne źródła energii;

kredyt Zielona inwestycja na zakup lub refinansowanie zakupu materiałów o charakterze ekologicznym, np. odnawialne źródła energii: kolektory słoneczne, ogniwa fotowoltaiczne, pompy ciepła, przydomowe wiatraki, instalacje mikrokogeneracyjne, instalacje odzysku ciepła, w tym rekuperatory, gruntowe wymienniki ciepła, przydomowe oczyszczalnie ścieków i wiele innych;

kredyt z premią ekologiczną z przeznaczeniem na ekomodernizację skierowany do wspólnot mieszkaniowych, a także osób zarząazających nieruchomościami; EKOpożyczka Zielona inwestycja na zakup lub refinansowanie zakupu materiałów o charakterze ekologicznym. 


\section{wielkopolskie}

- modernizacja systemów grzewczych, inwestycje w odnawiane źródła energii

i kogenerację, usuwanie PCB, zakup, instalacja i modernizacja oczyszczalni

ścieków, termomodernizacja, przyłącza kanalizacyjne, usuwanie azbestu

\section{lubuskie}

- modernizacja systemów grzewczych i wykorzystanie OZE, termomodernizacja, przydomowe oczyszczalnie ścieków i przyłącza kanalizacyjne, usuwanie azbestu

\section{kujawsko-pomorskie}

- modernizacja źródeł ciepła, docieplenie budynków, budowa płyt obornikowych, zagospodarowanie odpadów, przydomowe oczyszczalnie ścieków, produkcja biomasy, usuwanie azbestu, konserwacja parków, zakup sprzętu do ratownictwa

chemiczno-ekologicznego, oświetlenie energooszczędne

\section{opolskie}

- usuwanie azbestu, inwestycje energooszczędne i odnawialne źródła energii, zadania w ramach sanitacji

\section{warmińsko-mazurskie}

- inwestycje w zakresie OZE, termodernizacja, małe oczyszczalnie ścieków, usuwanie azbestu, inwestycje w czystszą produkcję

\section{podkarpackie}

•przedsięwzięcia związane z ochroną środowiska

Rysunek 9. Oferta kredytów preferencyjnych BOŚ SA z dopłatami WFOŚiGW

Źródło: Opracowanie własne na podstawie wewnętrznych materiałów BOŚ SA

Analizując ofertę kredytową BOŚ SA, należy zaznaczyć, iż oferta ta jest dostosowywana do potrzeb rynkowych. Przykładem tego jest uruchomienie w sierpniu 2017 roku EKOkredytu PV skierowanego do osób fizycznych na zakup i montaż fabrycznie nowych instalacji fotowoltaicznych lub refinansowanie nabycia instalacji. Do stycznia 2018 roku bank udzielił 427 kredytów na łączną kwotę 9881845 zł (Rysunek 10). 


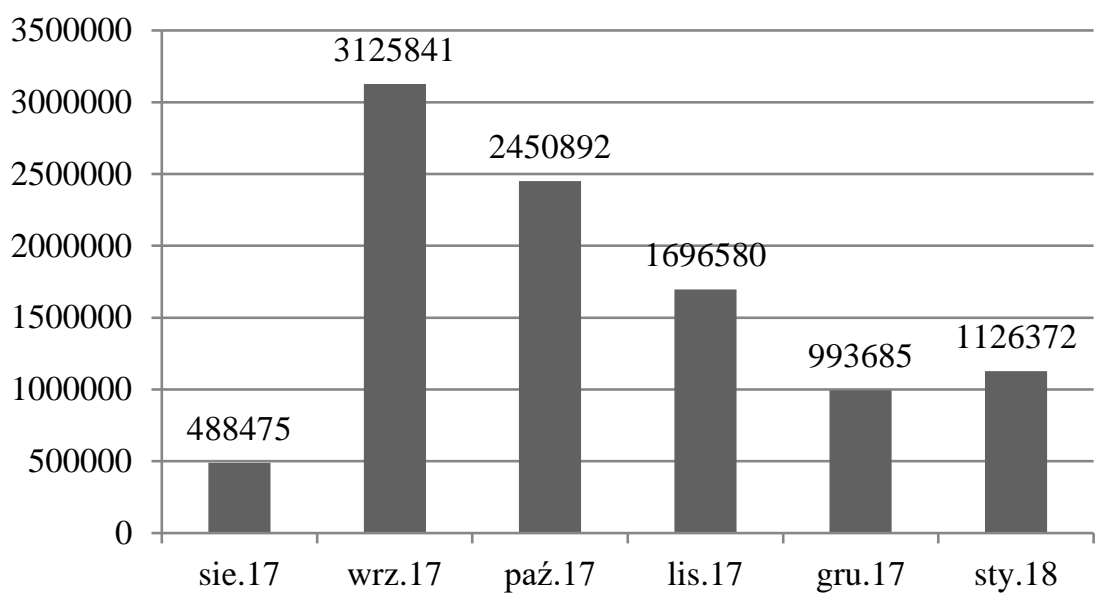

\section{Rysunek 10. Struktura udzielonego kredytu EKOkredyt PV}

Źródło: Opracowanie własne na podstawie wewnętrznych materiałów BOŚ SA

Analizując dane zamieszczone na Rysunku 10, można by stwierdzić, że na ten typ inwestycji proekologicznych jest mniejszy popyt, o czym świadczy spadek ilości udzielanych kredytów. Należy jednakże wziąć pod uwagę fakt, iż montaż instalacji fotowoltaicznych rozpoczyna się w okresie wiosennym, a kończy późną jesienią. Zatem popyt na ten kredyt wzrastać będzie z początkiem roku.

Obok EKOkredytu PV BOŚ SA oferuje, jako jedyny bank w kraju, kredyt preferencyjny z dotacją na finansowanie zakupu i montażu mikroinstalacji odnawialnych źródeł energii ze środków NFŚiGW - EKOkredyt Prosument II. Kredyt ten stanowi już drugą jego edycję, a kierowany jest do klientów indywidualnych oraz wspólnot i spółdzielni mieszkaniowych. Strukturę udzielanego kredytu przedstawiono na Rysunku 11.

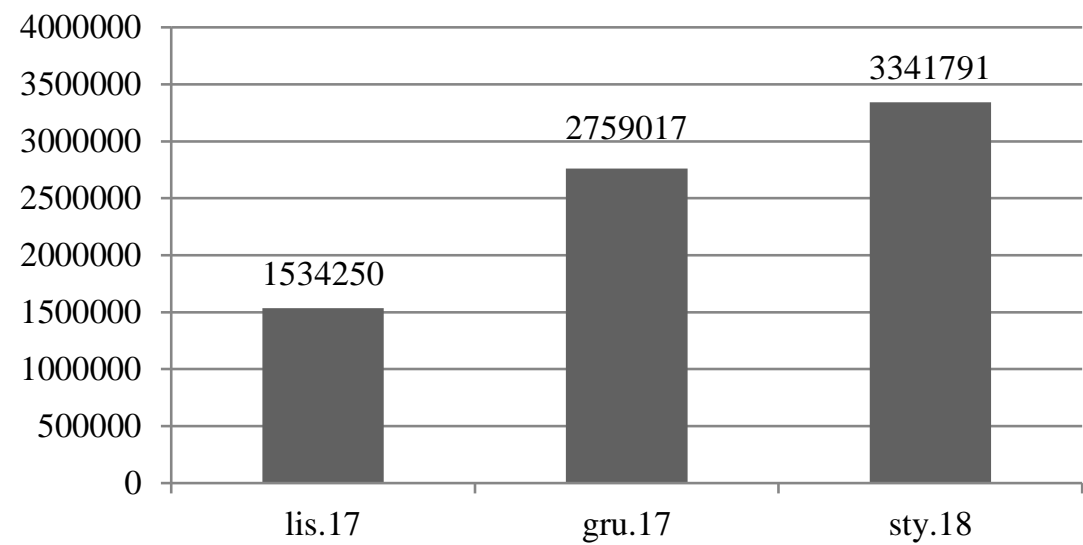

\section{Rysunek 11. Struktura udzielonego kredytu EKOkredyt Prosument II}

Źródło: Opracowanie własne na podstawie wewnętrznych materiałów BOŚ SA 
W okresie 3 miesięcy kredyt ten przyznano 330 inwestorom, z przeznaczeniem głównie na następujące instalacje:

źródła ciepła opalane biomasą o zainstalowanej mocy cieplnej do $300 \mathrm{kWt}$,

pompy ciepła o zainstalowanej mocy cieplnej do $300 \mathrm{kWt}$,

kolektory słoneczne o zainstalowanej mocy cieplnej do $300 \mathrm{kWt}$,

małe elektrownie wiatrowe o zainstalowanej mocy elektrycznej do $40 \mathrm{kWe}$, a także zakup i montaż małych instalacji lub mikroinstalacji odnawialnych źródeł

- do produkcji energii elektrycznej lub ciepła.

\section{- Podsumowanie}

Reasumując rozważania niniejszego opracowania, należy stwierdzić, iż BOŚ SA w dalszym ciągu odgrywa dużą rolę w systemie finansowania przedsięwzięć proekologicznych. Proekologiczna aktywność banku jest wyrazem zainteresowania wspieraniem inwestycji służących poprawie jakości środowiska, fachowej wiedzy i aktywności w pozyskiwaniu środków pochodzących ze źródeł pozabankowych. Ponadto BOŚ SA w proekologicznej działalności upatruje atrakcyjny obszar inwestowania i źródło popytu na finansowanie inwestycji środowiskowych.

O zaistniałym fakcie świadczy stale zwiększająca się liczba kredytów proekologicznych, dostosowana do potrzeb rynkowych, jak również stała współpraca z NFOŚiGW, a także WFOŚiGW. Co więcej, wieloletnie zaangażowanie BOŚ SA w finansowanie projektów służących ochronie środowiska zaowocowała znaczącym jego wkładem w poprawę stanu środowiska w całym kraju. Dla przykładu można podać uzyskane efekty zakończonych w 2016 roku projektów inwestycyjnych finansowanych przez BOŚ SA, takie jak: redukcja emisji pyłów, dwutlenku siarki, tlenków azotu, dwutlenku węgla, zmniejszenie zużycia i strat ciepła, unieszkodliwienie odpadów, produkcja energii w OZE.

\section{Literatura}

1.

Barczak A., Kowalewska E. (2014), Źródta finansowania zadań z zakresu ochrony środowiska $w$ Polsce - przeglad stosowanych rozwiazań, „Prawo Budżetowe Państwa i Samorządu", nr 1(2), s. 37-58. DOI: 10.12775/PBPS.2014.003

Ciechanowicz-McLean J. (2009), Prawo i polityka ochrony środowiska, Wolters Kluwer, Warszawa.

Famielec J. (2005), System finansowania ochrony środowiska w Polsce, Wydawnictwo Akademii Ekonomicznej w Krakowie, Kraków.

Gabryś M. (2007), Znaczenie banków w finansowaniu ochrony środowiska $w$ Polsce na przykładzie Banku Ochrony Środowiska S.A., [w:] Nalepka A. (red.), Organizacje komercyjne i niekomercyjne wobec wzmożonej konkurencji i rosnacych wymagań konsumentów, VI Seminarium Młodych Pracowników Nauki, Doktorantów i Adiunktów, Ząb/Zakopane, 18-19 czerwca 2017 r., Wyższa Szkoła Biznesu, Nowy Sącz, s. 184-199.

Kłos L. (2015), Źródła finansowania ochrony środowiska w Polsce, „Prace Naukowe Uniwersytetu Ekonomicznego we Wrocławiu”, nr 395, s. 129-138. DOI: 10.15611/pn.2015. 395.12

Kościelniak H. (2014), Innowacje w zrównoważony rozwój transportu, „Logistyka”, nr 6, s. $5732-5736$. 
Macherzyński B., Nowodziński P. (2017), Ekoinnowacje jako instrument zarządzania w przedsiębiorstwach, [w:] Jelonek D., Nowodziński P. (red.), Sektor nowoczesnych ustug dla biznesu. Fundament rozwoju miasta - regionu - uczelni, Oficyna Wydawnicza Stowarzyszenia Menedżerów Jakości i Produkcji, Częstochowa, s. 53-60.

MŚ (2016), Informacja na temat źródeł finansowania zadań z zakresu ochrony środowiska w Polsce, roli Narodowego Funduszu Ochrony Środowiska i Gospodarki Wodnej oraz wojewódzkich funduszy ochrony środowiska i gospodarki wodnej oraz stanu wykorzystania środków finansowych na ochrone środowiska, Ministerstwo Środowiska, Departament Funduszy Ekologicznych, Warszawa.

NFOŚiGW (2009), Odnawialne źródto finansowania - 20 lat na rzecz ekorozwoju, Narodowy Fundusz Ochrony Środowiska i Gospodarki Wodnej, Warszawa.

Poskrobko B., Ejdys J. (2005), System ochrony środowiska w Polsce, [w:] Kozłowska B. (red.), Instrumenty polityki ekologicznej, PAN, Łódź.

9. Poskrobko B., Poskrobko T. (2012), Zarządzanie środowiskiem w Polsce, PWE, Warszawa System finansowania ochrony środowiska w Polsce (2013), XIX Konferencja Narodów

10. Zjednoczonych w sprawie Zmian Klimatu COP 19, Warszawa.

11. Toruński J., Wyrębek H. (2010), Znaczenie sektora bankowego w finansowaniu ochrony

12. Środowiska w Polsce na przykładzie BOŚ w latach 2000-2007, „Zeszyty Naukowe SGGW w Warszawie. Polityki Europejskie, Finanse i Marketing”, nr 4(53), s. 18-26.

13. www.nfosigw.gov.pl

\title{
THE ROLE OF BOŚ SA IN THE FINANCING OF PROEKOLOGICAL PROJECTS
}

\begin{abstract}
In the study includes considerations related to the pro-ecological operation of the bank BOŚ SA, in particular to determine the role in financing environmental projects. The study has been divided into two parts. Thus, the considerations of the first part concentrate on the characteristics of the forms of financing of pro-ecological undertakings implemented on the Polish market. In the second part, the analysis of the offer of preferential pro-ecological loans granted by BOŚ SA.
\end{abstract}

Keywords: ecological performance, eco-credit, preferential loans, pro-ecological preferential loans, BOŚ SA 